\title{
Müze Pazarlaması Bağlamında Dünyada ve Türkiye'de En Çok Ziyaret Edilen Müzelerin Ziyaretçi Odaklı Web Tasarımları
}

\author{
Kübra Özarslan (Dr.) \\ ktanrikulu34@gmail.com \\ Orcid: 0000-0003-4003-6852
}

Başvuru Tarihi: 19.11.2018

Yayına Kabul Tarihi: 18.02.2019

Yayınlanma Tarihi: 22.07.2019

DOI: $10.17680 /$ erciyesiletisim. 485401

Özarslan, K. (2019). Müze Pazarlaması Bağlamında Dünyada ve Türkiye'de En Çok Ziyaret Edilen Müzelerin Ziyaretçi Odaklı Web Tasarımları. Erciyes İletişim Dergisi, 6 (2), 1065-1078. DOI:

10.17680 /erciyesiletisim.485401

\section{Öz}

İletişim teknolojilerinin gelişmesi ve yaygınlaşmasıyla birlikte, dijital medya kültürel mirasın sergilendiği alanlar olan müzelerin tanıtımlarında etkin bir araç olarak kullanılmaya başlanmıştır. Sanal ortamın kültürel mirasları paylaşmaya olanak tanıması, müzelere çok büyük firsat ve olanaklar sunmuştur. Günümüzde pek çok müze, sanal ortamın firsat ve olanaklarından faydalanarak, ziyaretçilerine ya da potansiyel ziyaretçilerine müze hakkında hem güncel veri akışı sağlamakta hem de ziyaretçilere yönelik çeşitli imkânlar sağlamaktadır. Böylece, hem müzelerinin tanıtımlarını yaparak kültür pazarlamasına katkı yapmakta hem de sanal kültürel içerik üretimi yapmaktadırlar. Web siteleri, dijital medya pazarlamasında önemli bir rol oynamaktadır. Çevrimiçi pazarlama stratejilerine önem veren müzelerin web siteleri, ziyaretçiler için oldukça kullanışlı imkânlar sağlamaktadırlar. Bu araștırmada, Türkiye'deki müzelerin web sitelerinin belirlenen belli başlı kriterler konusunda başarılı olup olmadığı sorusuna yanıt aranmıştır. Bu doğrultuda, dünyanın en çok ziyaret edilen müzelerinin web siteleri incelenmiş ve bu sitelerin ziyaretçilerine sağladığı kullanışlı uygulamaların toplamından bir örnek model ortaya çıkarılmıştır. Bu uygulamalar örnek modelin kriterleri olarak değerlendirilmiştir. Dünyanın en çok ziyaret edilen beş müzesi (Louvre Müzesi, Ulusal Çin Müzesi, Havacılık ve Uzay Müzesi, Metropolitan Sanat Müzesi, Vatican Müzeleri) ile Türkiye'nin en çok ziyaret edilen ilk üç müzesi (Konya Mevlana Müzesi, İstanbul Topkapı Sarayı Müzesi ve İstanbul Ayasofya Müzesi) bu kriterlere göre değerlendirilmiștir. Araștırmanın sonucuna göre, örneklemde incelenen Türkiye'nin en çok ziyaret edilen üç müzesinin web sitelerinin aynı kriterleri sağlamadığı görülmüştür. Ayrıca, değerlendirilen ölçütlere göre, Louvre Müzesi'nin resmi web sayfasının en başarılı web sayfası olduğu görülmüştür. Türkiye'deki en çok ziyaret edilen üç müzenin resmi web sayfalarının ise Louvre Müzesi'sinin ziyaretçilerine dijital olarak sağladığı pek çok imkânı sağlamadığı görülmüştür.

Anahtar Kelimeler: Müze Pazarlaması, Dijital Pazarlama, Pazarlama İletişimi, Kullanıcı Odaklı Web Tasarımı. 


\title{
In the Context of Museum Marketing User Centered Web Design of the Most Visited Museums in the World and Turkey
}

\author{
Kübra Özarslan (Ph.D.) \\ ktanrikulu34@gmail.com \\ Orcid: 0000-0003-4003-6852
}

Date Received: 19.11.2018

Date Accepted: 18.02.2019

Date Published: 22.07.2019

DOI: 10.17680/erciyesiletisim.485401

\begin{abstract}
With the development and spread of communication technologies, digital media has been used as an effective tool in the promotion of museums, which are the areas where cultural heritage is exhibited. The virtual environment has provided great opportunities and opportunities for museums to share cultural heritage. Today, many museums benefit from the opportunities and opportunities of the virtual environment, provide visitors and potential visitors both the current data flow about the museum and provide various opportunities for the visitors. Thus, they contribute to cultural marketing by promoting their museums and produce virtual cultural content. Websites play an important role in digital media marketing. The websites of the museums, which give importance to online marketing strategies, provide very useful opportunities for the visitors. In this study, it was investigated are the museums' websites in Turkey whether successful in some specified criteria. In this context, the websites of the most visited museums of the world have been examined and a sample model has been created from the sum of the useful applications that these sites provide to their visitors. These applications were evaluated as the criteria of the sample model. The world's most visited five museums (Louvre Museum, The National Museum Of China, National Air and Space Musuem, Metropolitan Museum of Art, Vatican Museums) with Turkey's most visited top three museums (Konya Mevlana Museum, Istanbul Topkapi Palace Museum and Istanbul Hagia Sophia Museum were evaluated according to these criteria. According to the survey, three of Turkey's most visited museum of websites have been unsuccessful in the same subjects. The Louvre Museum's official website is the most successful web page according to the evaluation criteria.
\end{abstract}

Keywords: Museum Marketing, Digital Marketing, Marketing Communication, User Centered Design. 


\section{Kavramsal Çerçeve}

Son yıllarda "Türkiye bir dünya markası olabilir mi?" ya da "Türkiye’ye özgü markalar yaratılabilir mi?" sorusu Türkiye'nin gündeminde tartışılmaktadır. Batı (2015)'ya göre, bu konudaki fikirlerin bir kısmı henüz dünya markası çıaramayan bir ülke için zor gibi gözüktüğü yönünde olsa da, doğru markalama stratejisi ile her şey mümkündür. Ancak, bir dünya markası yaratmak sadece pazarlama stratejisi ile mümkün değildir; bütünsel olarak strateji ve kalite en önemli etkenlerdir. Batı (2015)'ya göre, Türkiye'nin tanıtımına katkıda bulunmak için markalama çalışmaları yapmak gerekmektedir. Kültür ve Turizm Bakanlığı'nın sitesinde yer alan pazarlama stratejileri ve iletişim hedefleri; 'Türkiye'nin pazar payının ve toplam ziyaretçi sayısının artırılması, Türkiye'ye gelen üst gelir grubu ziyaretçilerin payının artırılması, mevsimselliğin azaltılarak turizm talebinin on iki aya yayılması ve kültür, golf, kış, kongre, yatçılık, şehir, gençlik, sağlık ve eko turizm gibi turizm çeşitlerine yönelik talebin artırılması' olarak belirlenmiştir. İletişim stratejilerinde ise özellikle şehir markalamalarının ön plana çıktığı destinasyon odaklı tanıtımın yapılması ve yaz turizminden farklı seyahat motivasyonlarına da odaklanılarak Türkiye'nin ürün çeşitliliğinin vurgulanması, kültürel ve sanatsal etkinlikler için çalışmalar yapılması ve dijital tanıtıma ağırlık verilmesi gerçekleștirilmesi gereken hedefler olarak belirlenmiştir. Batı (2015)'ya göre, Türkiye kültürel zenginlikleri ile dünya markası olmaya aday durumdadır ancak Türkiye'nin tanıtım çalışmalarında hep aynı noktaya odaklanılarak aslında tanıtımda ön plana çıkartıp farklılık yaratılabilecek özellikler etkin olarak kullanılmamaktadır. Destinasyon pazarlaması ile daha çok Akdeniz ülkeleri ile rekabet halinde olabilecek olan tatil alanlarına odaklanılırken, prestij sağlayacak on iki bin yıllık tarihi ve kültürelöğeler modernlik çatısı altında birleştirilip verilmemektedir (Batı, 2015, 330-332). Dünyaca ünlü marka danışmanı Wally Olins (Aktaran: Batı, 2015, 332). Türkiye markasına ilişkin görüşlerini “yükselen etkin bir ülke için gereken her özelliğe sahip olmak yönünde düşünebildiğim en çarpıcı örnek Türkiye'dir. Çünkü Türkiye coğrafi konum, doğa, teknoloji, siyasi etkinlik, kültür, sanat, spor ve tarih gibi unsurların hepsini içeriyor" şeklinde ifade etmiştir.

Bu bağlamda, müze pazarlaması oldukça önemli bir konu olarak ortaya çıkmaktadır. Öncelikle, Kültürve Turizm Bakanlığı'nın pazarlama stratejileri veiletişim hedeflerine bakıldığında, mevsimselliğin azaltılarak turizm talebinin tüm yıla yayılması hedefi ile müze pazarlaması oldukça ilişkilidir. Müzeler, tüm yıl ziyaretçi çekebilecek olan kurumlardır. Ayrıca, destinasyon odaklı tanıtımın yapılması ve yaz turizminden farklı seyahat motivasyonlarına da odaklanılarak Türkiye'nin ürün çeşitliliğinin vurgulanması, kültürel ve sanatsal etkinlikler için çalışmalar yapılması hedefleri de müze pazarlaması ile oldukça ilişkilidir. Müze pazarlaması Kültür Bakanlı̆̆ı'nın hedef ve stratejilerini gerçekleştirebilmesi için önemli bir unsur olarak ortaya çlkmaktadır. Olins'in (Aktaran: Batı, 2015, 332). Türkiye'nin kültürel unsuruna dikkat çekmesi de müze pazarlamasının önemini ortaya koymaktadır. Ayrıca Batı (2015)'nın Türkiye'ye prestij sağlayacak on iki bin yıllık tarihi ve kültürel öğeler modernlik çatısı altında birleştirilip markalaşamadığı konusundaki vurgusu da müze pazarlamasının önemini ortaya koymaktadır.

Türkiye'deki müzelerin pazarlama konusunda başarılı olabilmesi için modern pazarlama iletişimi stratejileri uygulaması ve müzeleri ziyaretçilerin istek ve beklentilerine cevap veren başarılı birer markaya dönüştürmesi gerekmektedir. Böylece potansiyel müze ziyaretçilerinde müze hakkında olumlu bir tutum yaratılacak 
ve potansiyel ziyaretçiler gerçek ziyaretçilere dönüşecektir. İletişim teknolojilerinin gelişmesiyle birlikte, müzelerin potansiyel ziyaretçilere ulaşmalarının yöntemleri de gelişmiş, çeşitlenmiş ve hızlanmıştır. Örneğin, günümüzde pek çok müze ziyaretçilerine; gerek sosyal medya platformları gerek mobil uygulamalar gerekse kurumsal web siteleri aracılığıyla ulaşabilmekte, onların ihtiyaç ve beklentilerini bu araçlar ile karşılayabilmektedir. Müzelerin dijital araçları kullanarak tüm dünyadan potansiyel müze ziyaretçileri iletişime geçmesi özellikle gelecek kuşakların yaşam tarzını düşünüldüğünde daha da önem kazanmaktadır. Sarı ve Kozak (2005, p.249)'a göre de, eğitim düzeyi daha yüksek, bilinçli, talep ve beklentileri daha yoğun olması beklenen geleceğin tüketicileri ve turistlerinin, tüketim alışkanlıkları, yaşam tarzları, davranış biçimleri turizm politika ve planlamacılarınca yakından izlenmek durumundadır. Bu sebeple de, turist çeken ülkeler ve ülke tanıtımından sorumlu ulusal turizm örgütleri, dünya turizm pazarında rekabetin giderek keskinleștiği, pazardaki turizm bölgesi ve ürün sayısının her geçen gün arttığı günümüzde, pazar paylarının korunması için çağdaş teknolojiden yararlanarak sürekli çaba harcanması gereğini açıkça görmektedirler. Dolayısıyla, tüketici odaklı bir pazarlama iletişimi müzelerin markalaşması için olmazsa olmazdır.

Mal ve hizmetlerin tüketiciler tarafından fark edilip satın alınması ile başlayan ve satış sonrası tüketici memnuniyetinin sağlanmasına kadar devam eden sürece pazarlama iletişimi adı verilmektedir. İki taraflı bir iletişim olan pazarlama iletişimi sürecinde iki yönlü bilgi ve deneyim alışverişi gerçekleștirilmektedir. Teknolojinin gelişmesi, iki yönlü iletişime yeni olanak sağlamıștır. Pazarlama, bugünkü noktasına gelinceye değin üç önemli evreden geçmiştir: Üretim odaklı pazarlama, kitlesel üretim dönemi ve tüketici odaklı pazarlama. Tüketici odaklı pazarlama döneminde, tüketiciler önceki dönemlerde olmadığı kadar pazarlama süreçlerinin odak noktası olmuşlardır. Bu durumun nedeni, 1980'lerin başında, yaşam tarzlarının çeşitlenmesiyle müşteri gruplarının küçülmeye başlamasıdır. Pazarlama iletişimi, çeşitlenen yaşam tarzlarının satın alma alışkanlıklarına, istek ve ihtiyaçlarına göre planlanmaya başlanmıştır. Bir diğer ifadesiyle, günümüzde müșteri ve olası müşterilerin talep ve beklentilerini merkeze alan yeni pazarlama anlayışı uygulanmaya başlanmıştır. "Modern pazarlama anlayıșı" olarak da adlandırılan bu anlayışın temel özelliği, pazarlama sistemine iletişim olgusunu katması ve müşteri odaklı olmasıdır (Bozkurt, 2014, 16-22). Bozkurt (2014, 4344)'a göre, günümüzde, pek çok şirket modern pazarlama anlayıșını uygulama konusunda başarılı değildir çünkü pek çok kurum ve kuruluş üretim konusundaki performansını pazarlama iletişimi konusunda gösterememektedir. Bu durum da örgüt ve markalar ile ilgili tüketicilerde olumsuz bir tutum oluşmasına neden olmaktadır. Tutumları, tüketicilerin herhangi bir konuya ilișkin aldığı tavır, olumlu ya da olumsuz pozisyon olarak tanımlamak mümkündür. Tüketicilerin bir marka ya da kurumla ilgili tutumlarının oluşmasında dört çeşit mesaj etkili olmaktadır: Planlanmış mesajlar, planlanmamış mesajlar, taşınan mesajlar ve algılanan mesajlar. Planlanmış mesajlar, firma ya da kurumun kendi amaç ve hedeflerini gerçekleştirmek için bir strateji izleyerek planladığı mesajlar olarak ifade edilebilir. Halkla ilişkiler çalışmaları, satış noktası etkinlikleri, reklamlar gibi kontrol edilebilir mesajlar bu gruba en iyi örnektir (Bozkurt, 2014, 43-44). Bu bağlamda, pazarlama iletişimi sürecinde tüketici davranışlarının istenilen yönde gerçekleşmesi için kurumun planlanmış mesajları oldukça önemlidir. 
Günümüzde pek çok müze interneti ve sosyal medyayı etkin bir şekilde kullanarak tüketici odaklı pazarlama iletişimi stratejileri benimsemektedir. Üstelik müzelerin markalaşma süreci hiç de yeni değildir. Geçtiğimiz yirmi beş yıl boyunca, müzeler ve sanat organizasyonları yönetimsel bir araç olan pazarlamanın kademeli olarak farkına varmıştır ( Rentschler, 2002, 7). Birçok müze, kullanıcılara pek çok imkân taniyan World Wide Web'in (Web) multimedya özelliklerini kullanarak sanat eserlerini büyütmelerini ve teknik ve tarihsel detaylara ulaşmalarını sağlayan teknik altyapıya yatırım yapmıştır. 2004 yılına gelindiğinde, müzelerin \% 88'inin web siteleri bulunmaktaydı (Aktaran: Lopez ve diğerleri, 2010, 235). İnternet, çoğu durumda müzelere ve koleksiyonlarına erişimi olmayan kişiler olmak üzere milyonlarca insana müzelere ulaşma imkânı sağlamaktadır (Sarraf, 1999, 231). Pek çok müze, internetin bu imkânlarını tüm topluma yayacak şekilde etkilerini genişletmek ve profilini nispeten düşük bir maliyetle etkilerini yükseltmek için ellerinden geleni yapmaktadır (Reynolds, 1997). Müzeler, web sitelerini, koleksiyonlarını ek bilgilerle tamamlamak ve sunmak için kullanmaya devam etmektedirler. Web sitesi, aslında, müzeye ikinci, sanal bir hayat vermektedir (Sarraf, 1999, 231). Geçtiğimiz on yll boyunca, müze sektöründe önemli bir devrim olan kaynakların ziyaretçilere çevrimiçi olarak sunulması sessizce gerçekleştirilmiştir (Aktaran: Wilson, 2011,373). Müzelerin web siteleri 1990’larda yaratılan ve sadece bir bilgi birikimi sağlayan basit web sitesi tasarımlarından, modern çevrimiçi kataloglarına, sanal sergilere ve artık siber ziyaretçi için erişilebilir ve indirilebilir bir kaynak sunan içerik sağlayan tasarıma evrilmiştir (Aktaran: Wilson, 2011, 373).

\section{Araştırmanın Amacı Ve Önemi}

Türkiye de, Kültür ve Turizm Bakanlı̆̆ı'nın pazarlama stratejileri ve iletişim hedeflerinde açıkladığı gibi markalaşma hedefleri doğrultusunda, müze pazarlamasında da dijital tanıtıma ağırlık vermelidir. Ancak, Batı $(2015,332)$ 'nın da Türkiye'nin on iki bin yıllık tarihi ve kültürel öğeler modernlik çatısı altında birleştirilip verilmediğini belirtmesine paralel olarak, kültür pazarlaması çatısı altında yer alan müze pazarlamasının Türkiye'de etkin bir şekilde yönetilmediğine ilișkin çalışmalar mevcuttur. Örneğin, Özarslan (2018) “Türkiye'deki Müzeler Sosyal Medyada Etkin Bir Şekilde Tanıtılıyor Mu? : Instagram Örneği Üzerinden Avrupa Birliği Üyesi Ülkeler İle Karşılaştırmalı Bir Araştırma' adlı çalışmasında Türkiye'de müzelerin pazarlama iletişimi stratejileri doğrultusunda sosyal medyayı yeterince etkin bir şekilde kullanmadığı sonucuna varılmıştır:

“Bu çalışmada, Türkiye'deki müzelerin tanıtımında günümüzde oldukça popüler olan bir sosyal medya platformu olan Instagram'ın etkili bir araç olarak kullanıp kullanılmadığı sorusuna yanıt aranmıştır. Bu sorunun cevaplanabilmesi için Türkiye'deki müzelerin Instagram performansı ile Avrupa Birliği'ne üye olan yirmi sekiz ülkedeki müzelerin Instagram performansı karşılaştırmalı bir yöntemle incelenmiştir. Instagram performansı, bu çalışmada müzelerin Instagram üzerinden ürettiği sanal kültürel içeriklerin niceliğine işaret etmektedir. Araştırmanın örneklemi, günümüzde oldukça popüler bir seyahat uygulaması olan Tripadvisor'da her bir ülkenin en iyi müzeler sıralamasında yer alan ilk on müzesi olmak üzere iki yüz doksan müzedir. Araştırmanın sonucuna göre İspanya, toplam yirmi dokuz ülke içerisinde, Tripadvisor'da yer alan ilk on müzesinin Instagram hesaplarında üretilen toplam 7422 içerik ile birinci olmuştur. İspanya'yı, İngiltere, Danimarka, Fransa, 
İsveç ve Finlandiya takip etmektedir. Türkiye ise toplam 2319 içerik ile on birinci olmuştur." (Özarslan, 2018, 533).

Türkiye'deki müzelerin Instagram aracılığıyla ürettiği sanal kültürel içeriğin Avrupa Birliği üyesi yirmi sekiz ülke içerisinde nicel olarak on birinci olması Türkiye'deki müzelerin sosyal medyayı etkin bir şekilde kullanmadığı sonucunu doğurmaktadır. $\mathrm{Bu}$ durum, Türkiye'deki müzelerin pazarlama iletişimi ve markalaşması açısından olumsuz bir faktördür. Kotler $(2017,85)$ de kurumların mecraları kullanmak zorunda olduğunu, eğer kurumlar mecraları kullanmıyorsa pratikte de mevcut olmadığını belirtmektedir.

"İnternetin yaygınlaşması ve bilişim teknolojilerinin büyük bir hızla gelişmesi yeni bir iletişim çağının başlangıcı olarak görülmektedir. Ticari işlemler, internet üzerinden gerçekleşmeye başlamış ve zamanla internete bağımlı hale gelmiştir." (Erdoğdu ve Tanrıkulu, 2015, 276). Bu sebeple, dijital tanıtım önem kazanmıştır. İnternet, kurumlara, iletişimde bulunmak ve satmak için çok kullanışlı bir platform sağlamaktadır. İnterneti erken kucaklayan ve onu başarılı bir şekilde kullanan kurumlar, onu geç benimseyen rakiplerine göre harcamalarını azaltmaktadırlar (Kotler, 2017, 59-61). Bu noktada, müze pazarlaması doğrultusunda sosyal medyayı yeterince etkin bir şekilde kullanmayan Türkiye'deki müzelerin web sitelerini verimli kullanıp kullanmadığı sorusu da önem kazanmaktadır.

Kotler (2017)'e göre, bugün her kurumun, kendi kalitesini yansıtan bir web sitesine gereksinimi bulunmaktadır. Başarılı bir web sitesi, güzel fotoğraflarla dolu bir web sitesi değildir çünkü müşteriler ya da müze ziyaretçileri web sitesindeki resimlerin yüklenmesini beklemek konusunda genel olarak sabırlı değillerdir ve gösteri değil bilgi isterler. Web sitesi ziyaretçileri genel olarak, hızlı bir yüklenme, temiz bir başlangıç ekranı, diğer ekranlara kolay geçiş, kolay sipariş verme yöntemi ve anlaşılır bilgi arayışındadırlar (Kotler, 2017, 59-61). Bu sebeple, web siteleri hem şirketlerin hem de müzeler gibi resmi ya da gayri resmi kurumların dijital pazarlama stratejileri için oldukça önemlidir. Bozkurt $(2014,51)$ 'e göre de, web siteleri markalamayı, paketleme ve tüketici ürünleri için yapılan markalamalara göre daha doğrudan yapmaktadır. İnsanların en çok ziyaret ettikleri web sayfaları, en verimli olanlarıdır ve bu verimlilik ancak markalama ile sağlanabilir, çünkü bu sayfaların tüketicilerin kafasında oluşturduğu marka imajı ziyaretçilere "zaman ayırıp ziyaret ettiğimize değer" imajı vermelidir. Potansiyel müze ziyaretçilerinin karar verme aşamasında dijital medyanın önemli bir araç olduğu bilinmektedir. Örneğin Google’ın IAB (Uluslararası Reklamcılar Derneği) işbirliği ile gerçekleştirdiği araştırmaya göre batı odaklı toplumlarda çevrimiçi alışveriş yapmayan kitleler dahi satın alma öncesinde internette araştırma yapmaktadır. Araştırmaya göre dünya genelinde uçak, tatil, tur, iş gezisi vb. fiziki mekânlardan satın alan her 100 kişiden 85'i ön araştırmasını yine internet üzerinden yapmakta ve sosyal medyadan tavsiye almaktadır (Batı, 2015, 176).

Modern pazarlama iletişimi müşteri odaklı olduğundan kurumların ya da markaların web sitelerinin de müşteri memnuniyetini sağlamak amacıyla tasarlanması müzelerin markalaşması açısından oldukça önemlidir. Fırlar ve Okat Özdem (2013, 5)'e göre de, 'müşteri memnuniyeti' gibi örgütsel başarıyı temsil eden kriterlerin dijital ortamlarda da geçerli olduğu yargısı kabul görmektedir. Bu doğrultuda web sitelerinin, hedef kitleleri doğrultusunda amaca yönelik olarak 'işlevsel' biçimde 
tasarlanmaları gerekmektedir. Markalaşma ve müze pazarlaması açısından ziyaretçi gereksinimleri oldukça önemlidir. Kotler $(2017,100)$ 'e göre, pazarlamanın özgün formülü şudur: "gereksinimleri bul ve onları karşıla". Müzelerin web siteleri, ziyaretçilerin gereksinimlerine göre güncellenmeli ve yenilikçi olmalıdır. Geissler, Rucks \& Edison (2006)'un “Understanding the Role of Service Convenience in Art Museum Marketing: An Exploratory Study" başlıklı çalışmalarında katılımcılara "Bir müzenin adı ziyaret kararı verme sürecinde ne kadar etkilidir? Sizce bir müzeyi herhangi bir ürün gibi markalamak uygun mudur değil midir?" sorusu sorulmuş ve bir katılımcı bu soruyu "Bence bir sanat müzesini markalama terimi bir web sitesi ile benzerdir. İkisi de eğer değişmezse sıkıcı bir hale gelebilir. Kalıcılık konusunda geleneklerinin olması önemlidir ancak değişim hayatın heyecanıdır, değişim ve güncellik insanları müzeye yeniden getirmenin yoludur." şeklinde cevaplamıştır (Geissler ve diğerleri, 2006, 78). Dolayısıyla, web sitelerinin güncel ve ziyaretçi odaklı olması müze pazarlaması açısından oldukça önemlidir.

\section{Yöntem}

Bu araştırmanın amacı, Türkiye'deki müzelerin kurumsal web sitelerinin ne kadar işlevselleştirildiği, ziyaretçilerin istek ve beklentilerinin ne kadar sağlandığı, web sitesi aracılığıyla ziyaretçilere ya da potansiyel ziyaretçilere nasıl imkânlar sunulduğu sorusunu cevaplandırmaktadır. Bu amaçla, dünyanın en çok ziyaret edilen müzelerinin web siteleri taranmış ve bu sitelerde ziyaretçilere ya da potansiyel ziyaretçilere nasıl imkânlar sunulduğu incelenmiştir. Genel olarak, günümüzde, dijital tanıtımına ağırlık veren bu müzelerin web siteleri aracılığıyla ziyaretçilerine pek çok imkân sunduğu görülmüştür. Örneğin bu müzelerin pek çoğunun web sitesinde kullanıcılara çevrimiçi olarak bilet alma, çevrimiçi alışveriş yapma, sesli rehber ${ }^{1}$ indirebilme, açı ve kapalı saatler hakkında bilgiye ve aplikasyon tanıtımına ulaşabilme, müzeye bağıș yapabilme, sergi ve etkinlikler hakkında bilgi edinebilme, müzenin kat planlarını inceleyebilme, sosyal medya paylaşım butonları vasıtasıyla sosyal medya platformlarında paylaşım yapabilme, koleksiyon arşivi hakkında bilgi edinebilme gibi pek çok imkân sunulmuştur. Anılan bu uygulamalar, pazarlama iletişimi konusunda aktif olduğu görülen müzelerin web sitelerinde ziyaretçilere sunulan imkânların toplamı olup, örnek bir modelin kriterleri olarak belirlenmiştir. Örneklemde yer alan web siteleri de bu kriterlere göre incelenmiş ve değerlendirilmiştir.

Buna ek olarak, iyi bir web tasarımında olması gereken dört özellik daha bu kriterlere dâhil edilmiștir. Bunlar; ana sayfada yer alması gereken sık sorulan sorular butonu $^{2}$, kurum hakkında bilgi, web sitesinin dil seçeneği ve iletişim seçeneğidir. Toplam on dört kriter önceden belirlenmiş ve dünyanın en çok ziyaret edilen beș ${ }^{3}$, Türkiye'nin ise en çok ziyaret edilen ilk üç müzesinin web sayfaları bu kriterlere göre incelenmiştir. Dünyanın en çok ziyaret edilen müzelerinin müze pazarlaması bağlamında, dijital stratejilerine ve web sitesi tanıtımlarına/tasarımlarına bakılarak Türkiye'nin müzelerinin web sitelerinin tasarımları değerlendirilecek ve bir karşılaştırma yapma imkânı sağlanacaktır. Böylece Türkiye’nin dünyadaki başarılı uygulamalara bakılarak yeri saptanmaya çalışılacaktır. Ayrıca başarılı uygulamaların incelenmesiyle örnek model önerisi yapılacaktır.

\section{Bulgular}

Louvre Müzesi (Louvre Museum): Dünyanın en çok ziyaret edilen müzesi Fransa'da yer alan, 1793 yılında Fransız İhtilali'nden sonra açılan ilk devlet müzesi olan Louvre 
Müzesi'dir. Louvre Müzesi'nin resmi web sitesine www.louvre.fr/en linkinden erişilmektedir. Kurum hikayesi web sitesinin "History" [tarih] sekmesinde yer almaktadır ve buradan müzenin tarihine erişmek mümkündür. Louvre müzesinin web sitesinde, on farklı dil seçeneği yer almaktadır. Anasayfada sık sorulan sorular sekmesi yer almamaktadır. Açık kapalı saatler hakkında bilgi "Admissions and Directions" [Giriş ve Yönergeler] sekmesinde yer almaktadır. Çevrimiçi bilet seçeneği site ziyaretçilerine sunulmuştur. Sitede çevrimiçi alışveriş seçeneği bulunmamaktadır. Web sitesi, sesli rehber seçeneği sunmaktaktadır ve kullanıcılar bu çevrimiçi rehberi site üzerinden indirebilmektedirler. Sitede Louvre müzesinin aplikasyon tanıtımı yapılmaktadır. Sitede "Donate" [Bağış yap] sekmesi üzerinden bağış yapılabilmektedir. Anasayfada yer alan "exhibitions and events" [Sergiler ve etkinlikler] sekmesinden sergiler ve diğer etkinlikler hakkında bilgiye erişmek mümkündür. Ziyaretçiler, web sitesinde kat planlarına erişebilmektedirler. Web sitesinin çeşitli sayfalarında sosyal medya paylaşım butonları yer almaktadır. Anasayfada yer alan "Collection and Louvre Art" [Koleksiyon ve Louvre Sanatı] sekmesi üzerinden koleksiyon arşivi hakkında bilgiye erişmek mümkündür. Anasayfada iletişim seçeneği bulunmaktadır. Bu bağlamda, Louvre Müzesi incelenen on dört kriterin on ikisini sağlamaktadır.

Ulusal Çin Müzesi (The National Museum Of China): Çin'in başkenti Pekin'de bulunan ülkenin ana tarih ve sanat müzesidir. Müzeye www.en.chnmuseum.cn/ linkinden erişmek mümkündür. Potansiyel müze ziyaretçileri kurum hakkında bilgiye anasayfada yer alan "about us" [Hakkımızda] sekmesinden ulaşllabilmektedirler. Sitede dil seçenekleri bulunmaktadır. Sitenin anasayfasında "sık sorulan sorular" seçeneği yer almamaktadır. Müzenin açık olduğu saat ve günlere "opening hour" [Açılış saatleri] sekmesinden ulaşmak mümkündür. Sitede çevrimiçi bilet ve alışveriş seçeneği ziyaretçilere sunulmamıştır. Sitede sesli rehber hizmeti de yer almamaktadır. Sitede aplikasyon tanıtımı bulunmamaktadır. Sitede müzeye bağış yapma hizmeti yer almamaktadır. Sitede yer alan "events" [Etkinlikler] ve "exhibitons" [Sergiler] sekmelerinden sergi ve etkinlikler hakkında bilgilere ulaşmak "floor plans and halls" sekmelerinden ise kat planına ulaşmak mümkündür. Sitede sosyal medya paylaşım butonları bulunmamaktadır. Sitede "collections" [Koleksiyonlar] sekmesinden koleksiyon ve arşiv hakkında bilgiye ulaşmak mümkündür. Potansiyel müze ziyaretçileri sitede yer alan "contact us" [Bize ulaşın] sekmesinden yetkililere ulaşabilmektedirler. Bu bağlamda, "Çin Ulusal Müzesi” incelenen on dört kriterin yedisini sağlamaktadır.

Ulusal Havacılık ve Uzay Müzesi (National Air and Space Musuem): ABD'nin başkenti Washington'da bulunan müze 1946 yılında Ulusal Hava Müzesi adıyla açılmış olup dünyanın en büyük tarihi uçakların ve uzay araçları koleksiyonuna ev sahipliği yapmaktadır. Müzenin resmi web sitesine www.airandspace.si.edu/ linkinden erişilmektedir. "About" sekmesinden kurum hakkında bilgiye ulaşmak mümkündür. Sitede dil seçeneği ve sık sorulan sorular seçeneği bulunmamaktadır. Açık saatler hakkında bilgi ana sayfada yer alan "visit" [Ziyaret et] sekmesinde yer almaktadır. Çevrimiçi bilet ve alışveriş seçeneği web sitesinde yer almamaktadır. Sesli rehber hizmetine web sitesinde rastlanmamıştır. Sitede aplikasyon tanıtımı ve bağıș butonu yer almaktadır. Sergi ve etkinlikler hakkında bilgilere ana sayfada yer alan "exhibitions" [Sergiler] sekmesinden ulaşmak mümkündür. Kat planı sitede yer almamaktadır. Sosyal medya paylaşım butonları web sitesinde mevcuttur. 
Koleksiyonlar hakkında bilgiye ana sayfada yer alan "collections" [Koleksiyonlar] sekmesinden ulaşmak mümkündür. Ana sayfada iletişim sekmesi mevcuttur. $\mathrm{Bu}$ bağlamda, "Ulusal Havacılık ve Uzay Müzesi" incelenen on dört kriterin sekizini sağlamaktadır.

Metropolitan Sanat Müzesi (Metropolitan Museum of Art): Metropolitan Sanat Müzesi Anerika Birleşik Devletleri'ndeki en büyük sanat müzesidir. Müzenin resmi web sitesine www.metmuseum.org/ linkinden erişilmektedir. Kurum hakkında bilgiye anasayfa yer alan "About the met" [Met Hakkında] sekmesinden ulaşmak mümkündür. Sitede dil seçeneği ve sık sorulan sorular seçeneği yer almamaktadır. Müzenin açlk olduğu saat ve günlere "visit" [Ziyaret] sekmesinden ulaşmak ve "Buy ticket" [Bilet satın alma] sekmesinden çevrimiçi bilet almak mümkündür. Sitede ziyaretçilere, "Shop" [Alışveriş yap] sekmesinden alışveriş yapılabilme olanağı sunulmuştur. Sitede sesli rehber (Audio Guide) hizmeti verilmektedir. Sitede aplikasyon tanıtımına rastlanmamıştır. Sitede bağış butonu yer almaktadır. Anasayfada yer alan "Current Exhibitions" [Güncel sergiler] sekmesinden sergi ve etkinlikler hakkında güncel bilgilere erișmek mümkündür. Sitede "museum map" [Müze haritası] sekmesi mevcuttur ve potansiyel müze ziyaretçileri bu sekmeden kat planlarına erişebilmektedirler. Sitede sosyal medya paylaşım butonları mevcuttur. "The Met Collections" [Met Koleksiyonları] sekmesinden koleksiyonlar hakkında bilgiye erişmek ve "Contact Information" [Bilgi alma] sekmesi aracılığıla kurum ile iletişime geçmek mümkündür. Bu bağlamda, "Metropolitan Sanat Müzesi” incelenen on dört kriterin on birini sağlamaktadır.

Vatikan Müzeleri (Vatican Museums): Vatikan Müzeleri, Vatikan'da bulunan dünyanın en büyük müzelerinden birisidir. $\mathrm{Bu}$ müze Roma Katolik Kilisesi tarafından Rönesans'da inşa edilmiş olup, dünyanın önemli heykellerine ev sahipliği yapan önemli bir binadır. Müzeye www.museivaticani.va/content/museivaticani/ en.html linkinden erişilmektedir. Ziyaretçiler kurum hakkında bilgiye, "History" [Tarih] sekmesinden erişebilmektedirler. Sitede beş dil seçeneği bulunmaktadır. Sitenin ana sayfasında sık sorulan sorular sekmesi yer almamaktadır. Ziyaretçiler müzenin açık olduğu gün ve saatlere ana sayfada yer alan "Info" [Bilgi] sekmesinden erişebilmektedirler. Web sitesinde çevrimiçi bilet alma seçeneği ana sayfada yer alan "Tickets" [Biletler] seçeneği ile mümkündür. Ana sayfada yer alan "Store" [Alışveriş] sekmesinden alışveriş yapma imkânı bulunmaktadır. Sitede sesli rehber hizmetine ve aplikasyon tanıtımına rastlanmamıştır. Sitede "Support us" [Bizi destekleyin] sekmesinden bağış yapmak mümkündür. Sitede sergi ve etkinlikler hakkında bilgilere ve kat planlarına rastlanmamıştır. Sitede sosyal medya paylaşım butonları yer almaktadır ayrıca "Collections" [Koleksiyonlar] sekmesinde koleksiyon arşivi hakkında bilgilere ulaşmak mümkündür. Sitede iletişim seçeneği "Info" [Bilgi] sekmesi altında yer almaktadır. Bu bağlamda, Vatikan Müzeleri incelenen on dört kriterin dokuzunu sağlamaktadır.

Dünyanın en çok ziyaret edilen ilk beş müzesinin web sitesi tasarımlarını inceledikten sonra, Türkiye'nin en çok ziyaret edilen ilk üç müzesinin web tasarımını incelemek yerinde olacaktır. Böylece, Türkiye'deki müzelerin web sitelerini dünyada en çok ziyaret edilen müzelerin web siteleri ile karşılaştırma imkânı doğacaktır. Böyle bir karşılaştırma yapmak, Türkiye'nin müze pazarlaması bağlamında web tasarımı konusundaki durumunu tespit etmeyi sağlayacaktır. Türkiye'nin durumunu ve yerini tespit etmek, olası eksikliklerini saptamak ise müze pazarlaması 
konusunda uygulanması gereken dijital pazarlama stratejilerini geliștirme olanağı sağlayacaktır. Böylece Türkiye'deki müzeler, müze pazarlaması, turizm pazarlaması, sanal kültürel içerik üretimi, markalaşma gibi alanlarda dünyanın önde gelen müzeleri ile yarışır bir duruma gelebilecektir. T. C. Kültür ve Turizm Bakanlığı Kültür Varlıkları ve Müzeler Genel Müdürlügü'nün verilerine göre, 2017 yılında Türkiye’nin en çok ziyaret edilen müzeleri sırasıyla, 2.480.433 ziyaretçi sayısıyla Konya Mevlana Müzesi, 1.932.726 ziyaretçi sayısıyla İstanbul Topkapı Sarayı Müzesi ve 1.892.250 ziyaretçi sayısıyla İstanbul Ayasofya Müzesi'dir (Kültür ve Turizm Bakanlığı, t.y.). Bu müzelerin varsa İngilizce versiyonları incelenecektir.

Konya Mevlana Müzesi: Mevlana Müzesi, Konya'da bulunan, eskiden Mevlâna'nın dergâhı olan yapı kompleksinde 1926 yılından beri faaliyet gösteren müzedir. "Mevlana Türbesi" olarak da anılmaktadır. Mevlana Müzesine www.mevlana.gov. tr linkinden erişilmektedir. Anasayfada "Mevlana Museum" [Mevlana Müzesi] sekmesinden kurumun hikâyesine erişmek mümkündür. Web sitesinde bir dil seçeneği mevcuttur. Sitede "sık sorulan sorular" sekmesi yer almamaktadır. Sitede müzenin açık olduğu gün ve saatler hakkında bilgiye rastlanamamıştır. Sitede çevrimiçi bilet, çevrimiçi alışveriş seçeneği, sesli rehber seçeneği, aplikasyon tanıtımı, bağış butonu, sergi ve etkinlikler hakkında bilgi, kat planları hakkında bilgi, sosyal medya paylaşım butonları, koleksiyon ve arşiv hakkında bilgi mevcut değildir. Sitede iletişim seçeneği yer almaktadır. Bu bağlamda, incelenen on dört kriterden yalnızca üçünü sağlamaktadır.

Topkapı Sarayı Müzesi: Topkapı Sarayı, İstanbul Sarayburnu'nda, Osmanlı İmparatorluğu'nun 600 yıllık tarihinin 400 yılı boyunca, devletin idare merkezi olarak kullanılan ve Osmanlı padişahlarının yaşadığı saraydır. Müzenin resmi internet sitesine www.topkapisarayi.gov.tr linkinden erişilmektedir. Web sitesinde kurum hikâyesine "History" [Tarih] sekmesinden ulaşmak mümkündür. Sitede dil seçeneği bulunmakta ancak "sık sorulan sorular" sekmesi yer almamaktadır. Müzenin açık olduğu gün ve saatler hakkında bilgiye "Visit Hours" [Ziyaret saatleri] sekmesinden ulaşmak mümkündür. Web sitesi ziyaretçilerine çevrimiçi bilet alma imkânı sunulmuştur ancak çevrimiçi alışveriş imkânı sunulmamıştır. Ziyaretçilere sesli rehber hizmeti sunulmamıștır. Web sitesinde aplikasyon tanıtımı ve bağıș butonu yer almamaktadır. Anasayfada yer alan "Events and Exhibitions" [Etkinlikler ve Sergiler] sekmesinden etkinlik ve sergiler hakkında bilgilere ve "Tour Plan" [Tur Plânı] sekmesinden kat planlarına ulaşmak mümkündür. Sitede sosyal medya paylaşım butonları yer almaktadır. Anasayfada yer alan "Collections" [Koleksiyonlar] sekmesinden koleksiyon arşivi hakkında bilgiye ulaşmak ve "Contact" [İletişim] sekmesinden müze ile iletişime geçmek mümkündür. Bu bağlamda Topkapı Sarayı, incelenen on dört kriterden dokuzunu sağlamaktadır.

İstanbul Ayasofya Müzesi: Dünyanın en eski katedrali olan Ayasofya İstanbul'da tarihi bir müzedir. Müzenin resmi web sitesine www.ayasofyamuzesi.gov.tr linkinden erişilmektedir. Anasayfada yer alan "History" sekmesinden kurum hakkında bilgiye ulaşmak mümkündür. Sitede dil seçeneği bulunmaktadır. Anasayfada "Visit" [Ziyaret] sekmesi altında sık sorulan sorular sekmesi yer almaktadır. "Visiting Information" [Ziyaret bilgileri] sekmesi altında müzenin açık olduğu gün ve saatler hakkında bilgiye ulaşmak mümkündür. Ayrıca yine bu sekme altında ziyaretçilere çevrimiçi bilet alma hizmeti sunulmuştur ancak çevrimiçi alışveriş imkânı bulunmamaktadır. Web sitesinde sesli rehber sekmesi yer almaktadır ancak bu hizmet gișede 
verilmektedir ve siteden indirmeye açlmamıştır. Bu sebeple, bu kriterde başarısız sayılmasının daha uygun olacağı düșünülmüştür. Sitede aplikasyon tanıtımı ve bağış butonu yer almamaktadır. "News and Announcements" [Haberler ve duyurular] sekmesinden etkinlik ve duyurulara ulaşmak mümkündür. Sitede kat planlarına rastlanmamıștır. Sosyal medya paylaşım butonları sitede yer almaktadır. Koleksiyon arşivine "Collections" [Koleksiyonlar] sekmesinden ulaşmak ve ana sayfada yer alan "Contact us" [İletişim] sekmesinden müze ile iletişime geçmek mümkündür. $\mathrm{Bu}$ bağlamda İstanbul Ayasofya Müzesi incelenen on dört kriterin dokuzunu sağlamaktadır.

Tablo 1: Müzelerin Kullanıcı Odaklı Web Tasarımları

\begin{tabular}{|c|c|c|c|c|c|c|c|c|}
\hline $\begin{array}{l}\text { Kullanıcı Odaklı } \\
\text { Web Tasarımları } \\
\text { /Müzeler }\end{array}$ & $\begin{array}{l}\text { Louvre } \\
\text { Müzesi }\end{array}$ & $\begin{array}{c}\text { Ulusal } \\
\text { Çin } \\
\text { Müzesi }\end{array}$ & $\begin{array}{c}\text { Ulusal } \\
\text { Havacılık } \\
\text { ve Uzay } \\
\text { Müzesi }\end{array}$ & $\begin{array}{l}\text { Metropolitan } \\
\text { Sanat Müzesi }\end{array}$ & $\begin{array}{l}\text { Vatikan } \\
\text { Müzeleri }\end{array}$ & $\begin{array}{l}\text { Konya } \\
\text { Mevlana } \\
\text { Müzesi }\end{array}$ & $\begin{array}{l}\text { Topkapı } \\
\text { Sarayı } \\
\text { Müzesi }\end{array}$ & $\begin{array}{c}\text { İstanbul } \\
\text { Ayasofya } \\
\text { Müzesi }\end{array}$ \\
\hline $\begin{array}{l}\text { Kurum hakkında } \\
\text { bilgi }\end{array}$ & $\bullet$ & $\bullet$ & $\bullet$ & $\bullet$ & $\bullet$ & $\bullet$ & - & $\bullet$ \\
\hline Dil seçeneği & $\bullet$ & • & $x$ & $x$ & $\bullet$ & $\bullet$ & $\bullet$ & $\bullet$ \\
\hline $\begin{array}{l}\text { Sık sorulan } \\
\text { sorular }\end{array}$ & $x$ & $\mathrm{x}$ & $x$ & $x$ & $x$ & $x$ & $x$ & - \\
\hline $\begin{array}{l}\text { Açık ve } \\
\text { kapalı saatler } \\
\text { hakkında bilgi }\end{array}$ & $\bullet$ & - & - & $\bullet$ & $\bullet$ & $x$ & $\bullet$ & - \\
\hline $\begin{array}{l}\text { Çevrimiçi bilet } \\
\text { satın alma imkânı }\end{array}$ & $\bullet$ & $\mathrm{x}$ & $\mathrm{x}$ & $\bullet$ & $\bullet$ & $\mathrm{x}$ & - & $\bullet$ \\
\hline $\begin{array}{l}\text { Çevrimiçi alışveriş } \\
\text { seçeneği }\end{array}$ & $x$ & $\mathrm{x}$ & $\mathrm{x}$ & - & - & $\mathrm{x}$ & $\mathrm{x}$ & $\mathrm{x}$ \\
\hline $\begin{array}{l}\text { Sesli rehber } \\
\text { imkânı }\end{array}$ & - & $\mathrm{x}$ & $\mathrm{x}$ & $\bullet$ & $\mathrm{x}$ & $x$ & $x$ & $\mathrm{x}$ \\
\hline $\begin{array}{l}\text { Aplikasyon } \\
\text { tanıtımı }\end{array}$ & - & $\mathrm{x}$ & - & $\mathrm{x}$ & $\mathrm{x}$ & $\mathrm{x}$ & $x$ & $\mathrm{x}$ \\
\hline $\begin{array}{l}\text { Bağış yapma } \\
\text { seçeneği }\end{array}$ & $\bullet$ & $x$ & - & $\bullet$ & - & $x$ & $x$ & $\mathrm{x}$ \\
\hline $\begin{array}{l}\text { Sergi ve etkinlikler } \\
\text { hakkında bilgi }\end{array}$ & $\bullet$ & $\bullet$ & $\bullet$ & $\bullet$ & $\mathrm{x}$ & $\mathrm{x}$ & $\bullet$ & - \\
\hline $\begin{array}{l}\text { Kat planları } \\
\text { hakkında bilgi }\end{array}$ & $\bullet$ & - & $x$ & $\bullet$ & $x$ & $\mathrm{x}$ & $\bullet$ & $\mathrm{x}$ \\
\hline $\begin{array}{l}\text { Sosyal medya } \\
\text { paylaşım } \\
\text { butonları }\end{array}$ & - & $\mathrm{x}$ & $\bullet$ & - & - & $\mathrm{x}$ & - & $\bullet$ \\
\hline $\begin{array}{l}\text { Koleksiyon arşivi } \\
\text { hakkında bilgi }\end{array}$ & $\bullet$ & - & $\bullet$ & $\bullet$ & - & $\mathrm{x}$ & - & - \\
\hline İletişim seçeneği & - & - & - & - & - & - & - & - \\
\hline
\end{tabular}

\section{Sonuç ve öneriler}

Araştırmanın sonucuna göre, 2017 yılında dünyanın en çok ziyaret edilen müzesi olan Louvre Müzesi, incelenen on dört ölçütün on ikisini sağlayarak tüketici/ziyaretçi odaklı web sitesi tasarımı konusunda en çok ziyaret edilen diğer dört müzeden daha başarılı olmuştur. Web tasarımındaki başarı sıralamasına bakıldığında, Louvre Müzesini, sırasıyla on kriteri sağlayan Metropolitan Sanat Müzesi, dokuz kriteri sağlayan Vatikan Müzeleri, sekiz kriteri sağlayan Havacılık ve Uzay Müzesi ve yedi kriteri sağlayan Ulusal Çin Müzesi takip etmektedir. Türkiye'de en çok ziyaret edilen Konya Mevlana Müzesine bakıldığında ise incelenen kriterlerin yalnız üçünü, İstanbul Topkapı Sarayı Müzesi'nin ve İstanbul Ayasofya Müzesi'nin ise dokuz kriteri sağladığı görülmüştür. Türkiye'de incelenen her üç müzenin de ortak dört 
kriteri sağlayamadığı görülmüştür. Her üç müzenin web sitesinde de çevrimiçi alışveriş imkânı, sesli rehber hizmeti, aplikasyon tanıtımı ve bağıș butonları yer almamaktadır. Dünyanın en çok ziyaret edilen Louvre Müzesi'nin web sitesine bakıldığında çevrimiçi alışveriş ve sık sorulan sorular hariç bu özelliklerin tamamını sağladığı görülmektedir. Dijitalleşen dünyada, müze pazarlaması konusuna önem veren ve dijital pazarlama stratejilerini bu yönde geliştiren Louvre Müzesi gibi en iyi örneklerin uygulamalarına bakıldığında aplikasyon tanıtımına, sesli rehber hizmetine ve bağış butonlarına önem verildiği ve uygulandığı görülmektedir. Özellikle sesli rehber hizmeti teknolojinin kültürel gelişime sağladığı önemli bir firsattır. Müzelerin böyle bir fırsatı web siteleri aracılığıyla ziyaretçilerine sunması 'yeni nesil müzeciliği' oldukça iyi bir şekilde yansıtmaktadır. Yeni teknolojilerden yararlanma ve bu teknolojileri web siteleri aracılığıyla ziyaretçilere sunma konusunda Sesli rehber hizmeti oldukça ilerici, yenilikçi ve kullanışlı bir yöntemdir. Müzeler, sesli rehber hizmetini ücretli ya da ücretsiz sunarak, çevrimiçi alışveriş imkânı sağlayarak ve bağış butonları yardımıyla ek gelir edebilmektedirler. Böyle bir gelir, hem müzelerin daha kaliteli hizmet vermesi hem de bu hizmeti tüm dünyada etkin bir șekilde duyurmasını sağlayacak bir pazarlama iletişimi kampanyasını yürütmesi için bütçe yaratabilecektir. Türkiye'nin müzelerinin de markalaşmayı sağlaması, ziyaretçi sayısını artırması, tüm dünyada tanınması ve önemini artırması için dijital ortamda pazarlama iletişimine eğilmesi ve web site tasarımlarını yeni iletişim teknolojilerini en iyi ve yaratıcı şekilde kullanarak gerçekleştirmesi, ziyaretçilerine bu teknolojileri kullanarak hizmet vermesi oldukça önemlidir. Türkiye'deki müzelerin, gerek kurum içinde iletişim profesyonellerini istihdam ederek ya da kurum dışından bu hizmeti alarak istikrarlı bir pazarlama iletişimi stratejisi belirlemek ve uygulamak için yatırım yapmaları önemlidir.

\section{Notlar}

${ }^{1}$ Sesli rehber; bir avuç içi cihaz aracılığıyla müze ziyaretçilerine rehberlik yapmak amacıyla, sesli olarak önceden kaydedilmiş bilgileri aktarmaya yarayan teknolojiye verilen isimdir.

\footnotetext{
${ }^{2}$ Sık sorulan sorular kullanıcı rahatığı açııında ana sayfada yer almalıdır. Bu sebeple, sık sorula sorular sekmesi yalnızca ana sayfada aranacaktır. Eğer ana sayfada yoksa yok sayılacaktır.

3 "Themed Entertainment Association" ve "AECOM" tarafından yayınlanan Müze İndeksine göre 2017 yılında dünyanın en popüler müzeleri sırasıyla 1- "Louvre”, Paris, Fransa, 2-“Çin Ulusal Müzesi”, Beijing, Çin, 3-Ulusal Havacılık ve Uzay Müzesi”, Washington, Amerika Brileşik Devletleri, 4- "Metropolitan Sanat Müzesi”, New York, Amerika Birleşik Devletleri, 5-Vatikan Müzeleri, Vatican (Hunter, 2018).
}

\section{Kaynakça}

Batı, U. (2015). Tüketici davranışları. İstanbul: Alfa.

Bozkurt, İ. (2014). İletişim odaklı pazarlama. İstanbul: MediaCat.

Erdoğdu, B. A. ve Tanrıkulu, K. (2015). Panaptikon Düzenin Yeni Medya Ekonomisine Etkisi. T. Ayengin (Ed.). Uluslararası Yeni Medya Yeni Yaklaşımlar Konferansı Sosyal Medya Ve Yeni Politikalar (s.266-278). Çanakkale: Çomu Yayınları.

Fırlar, B. ve Okat, Özdem, Ö. (2013). Web Tasarımının Önemi: Destinasyon Web Sitelerinin Görsel Tasarımlarının Değerlendirilmesi. ODÜ Sosyal Bilimler Araştırmaları Dergisi, 4(7), 5-16. 
Geissler, G. L., Rucks, C. T. ve Edison, S. W. (2006). Understanding the role of service convenience in art museum marketing: an exploratory study [Sanat Müzesi Pazarlamasında Hizmetin Rolünü Anlamak: Bir Keşif Araştırması]. Journal of Hospitality \& Leisure Marketing, 14(4), 69-87. doi:10.1300/j150v14n04_05

Hunter, M. (2018). World's 20 Most Popular Museums. Erişim: 20.08.2018, https:// edition.cnn.com/travel/article/most-popular-museums-world-2017/index. html

İstanbul Ayasofya Müzesi Resmi Web Sitesi. (t.y.). Erişim: 20.08.2018, http:// ayasofyamuzesi.gov.tr

İstanbul Topkapı Sarayı Müzesi Resmi Web Sitesi. (t.y.). Erişim: 20.08.2018, http:// topkapisarayi.gov.tr

Konya Mevlana Müzesi Resmi Web Sitesi. (t.y.). Erişim: 20.08.2018, http://www. mevlana.gov.tr

Kotler, P. (2017). A'dan z'ye pazarlama. İstanbul: MediaCat Yayınları.

López, X., Margapoti, I., Maragliano, R. ve Bove, G. (2010). The presence of web 2.0 tools on museum websites: a comparative study between england, france, spain, italy, and the usa [Müzelerin Web Sitelerinde Web 2.0 Araçlarının Kullanımı: İngiltere, Fransa, İspanya, İtalya ve Amerika Birleşik Devletleri arasında Karşılaştırmalı Bir Araştırma]. Museum Management and Curatorship, 25(2), 235-249. doi:10.1080/09647771003737356

Louvre Museum Resmi Web Sitesi (t.y.). Erişim: 29.09.2018, https://www.louvre.fr/ en

Metropolitan Museum of Art Resmi Web Sitesi (t.y.). Erişim: 29.09.2018, https:// www.metmuseum.org/

National Air and Space Musuem Resmi Web Sitesi (t.y.). Erişim: 27.09.2018, https:// airandspace.si.edu/

Özarslan, K. (2018). Türkiye'deki Müzeler Sosyal Medyada Etkin Bir Şekilde Tanıtılıyor Mu? : Instagram Örneği Üzerinden Avrupa Birliği Üyesi Ülkeler İle Karşılaştırmalı Bir Araștırma, The Journal of Academic Social Science, 6(77), 533-557. doi:http://dx.doi.org/10.16992/ASOS.14079

Rentschler, R. (2002). Museum and performing arts marketing: the age of discovery. the journal of arts management [ Müze ve Performans Sanatı Pazarlaması: Keşif Çağl]. Law, and Society, 32(1), 7-14. doi:10.1080/10632920209597330

Reynolds, R. (1997). Museums and the Internet: What purpose should the information supplied by museums of the world wide web serve? Unpublished master's thesis, Museum Studies Department, University of Leicester, Leicester, England.

Sarı, Y. ve Kozak, M. (2005). Turizm Pazarlamasına İnternetin Etkisi: Destinasyon Web Siteleri İçin Bir Model Önerisi. Akdeniz İ.I.B.F. Dergisi (9), 248-271.

Sarraf, S. (1999). A survey of museums on the web: who uses museum websites? [Web Sitesindeki Müzeler Üzerine Bir Araștırma: Müze Web Sitelerini Kim Kullaniyor?]. Curator: The Museum Journal, 42(3), 231-243. 
T. C. Kültür ve Turizm Bakanlığı Kültür Varlıkları ve Müzeler Genel Müdürlüğü. (t.y.). Müze İstatistikleri. Erişim: 28.09.2018, http://www.kulturvarliklari.gov.tr/ TR-43336/muze-istatistikleri.html

The National Museum Of China Resmi Web Sitesi (t.y.). Erişim: 27.09.2018, http:// en.chnmuseum.cn/

Vatican Museums Resmi Web Sitesi (t.y.). Erişim: 27.09.2018, http://www. museivaticani.va/content/museivaticani/en.html

Wilson, R. J. (2011). Behind the scenes of the museum website [Müze Web Sitelerinin Sahne Arkasi]. Museum Management and Curatorship, 26(4), 373-389. doi:10. 1080/09647775.2011.603934 